\title{
Land use change impact on soil organic matter. Loess landscape case study
}

\begin{abstract}
The aim of this article is to establish how land use change influences soil organic matter content in the loess landscape. The research was conducted near Krasnystaw in the Lublin Upland, in forest, on arable land and on abandoned lands at various stages of secondary succession. During the field research, samples were collected from the upper soil layer and analyzed for organic carbon content, fractional composition of humus compounds and soil reaction. The results obtained indicate that the impact of land use change manifests itself in a change of the soil reaction, which turns from neutral or slightly acid into acid. The tillage system reduces organic matter in the soil and increases the humic acids ratio, whereas abandonment of the land causes an evident increase in the soil's organic matter content and the fulvic acids ratio. These results allow us to state that land use change has a rapid impact on the geochemical properties of the landscape (which can be noticed as soon as 5 years after the land is abandoned).
\end{abstract}

Keywords

Land use change $\bullet$ Soil organic matter $\bullet$ Loess landscapes

(C) University of Warsaw - Faculty of Geography and Regional Studies

\section{Introduction}

In physical geography, the notion of "landscape" can be understood in a number of ways (Ostaszewska 2002, Richling, Solon 2011, Chmielewski 2012). In the field of landscape geochemistry it is usually identified with the geosystem, a dynamic spatial system that consists of nature components connected by the migration of nutrient and chemical compounds (Perelman 1971, Ostaszewska 1992). In natural uninterrupted conditions, all the components of the landscape are connected, the geosystem as a whole is in equilibrium and there are stable relationships between the energy and matter that flow, transform and accumulate (Widacki 1979).

The soil and vegetation are parts of the system that are affected the fastest by changes in the landscape (Richling 1982). This means that the soil can be considered a reliable indicator of such changes (Degórski 2005) as a change in one component of the system leads to changes in the others. So when a forest ecosystem turns into a tillage system, deforestation causes a disturbance in the nutrient cycle and energy flow and affects the geochemical balance of the landscape as a whole. Yet abandoning of the land leads to the closure of the matter cycle and energy flow, which implies slow restoration of the geochemical equilibrium of the geosystem.

This article aims to analyze how land use change (from forest into a tillage system) influences soil organic matter, as well as to demonstrate which geochemical equilibrium restoration mechanisms occur when the land is abandoned.

\author{
Agnieszka Sosnowska \\ Institute of Physical Geography, \\ Faculty of Geography and Regional Studies, \\ University of Warsaw, \\ e-mail: ajsosnowska@gmail.com \\ Received: 29 May 2012 \\ Accepted: 29 October 2012
}

The research was conducted in the Lublin Upland in an area called Działy Grabowieckie near the town of Krasnystaw (Kondracki 2009). This landscape is characteristic because of the upper Cretaceous marls present in the bedding that are covered by a loess layer of varying thickness. The relief is diverse, characterized by many ravines and erosion slits. The drop between valleys and elevations can reach over $100 \mathrm{~m}$.

Działy Grabowieckie is situated on the boundary of the mixed forest and forest-steppe zones. The potential vegetation of the area consists of mixed beech and sycamore forest, as well as thermophilous oak and steppe grasslands. The contemporary landscape of the area is dominated by arable lands that generally account for around $80 \%$ of the Lublin Upland area. Forest appears in small patches, mainly in ravines and on steep slopes and accounts for only a few percent of the area (Baran-Zgłobicka et. al. 2001)

Four land use types were chosen for detailed examination in the study: arable, forest and two areas of abandoned land with secondary succession (one that was abandoned 5 years ago and another that was abandoned 20 years ago). The forest consisted of 80 -year-old beeches (Fagus sylvatica $L$.). The plot of arable land that had been abandoned for 5 years was covered with wood small-reeds (Calamagrostis epigios L.) and various genres of goldenrods (Solidago), along with a small number of birch seedlings (Betula pendula L.). The plot of arable land that was abandoned 20 years ago was covered by silver birch (Betula pendula L.). The areas studied during the research were located on Anthric Luvisols and Stagnic Luvisols, formed 
MISCELLANEA GEOGRAPHICA - REGIONAL STUDIES ON DEVELOPMENT

Vol. 16 • No. 2 - 2012 • pp. 11-15 • ISSN: 2084-6118 • DOI: 10.2478/v10288-012-0027-0

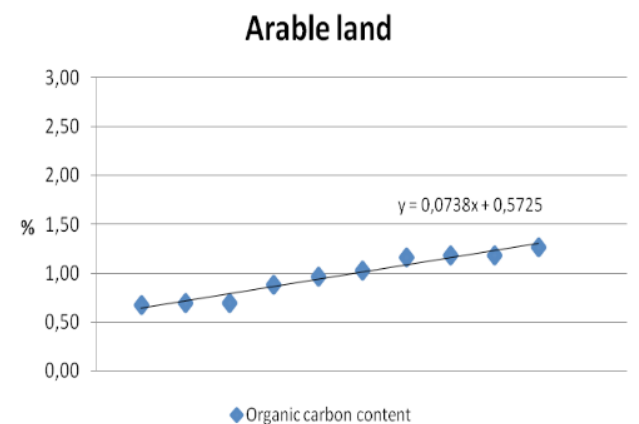

Abandoned land (20 years)

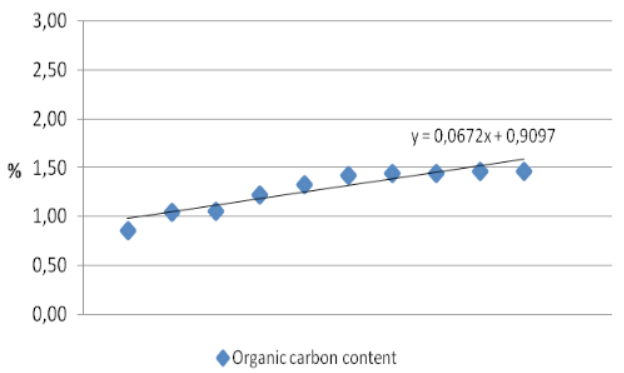

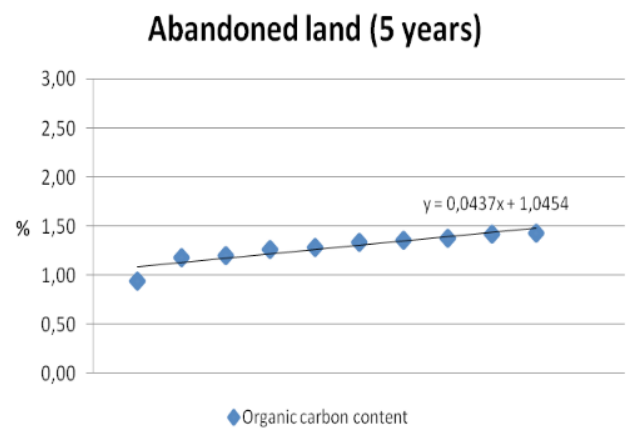

Forest

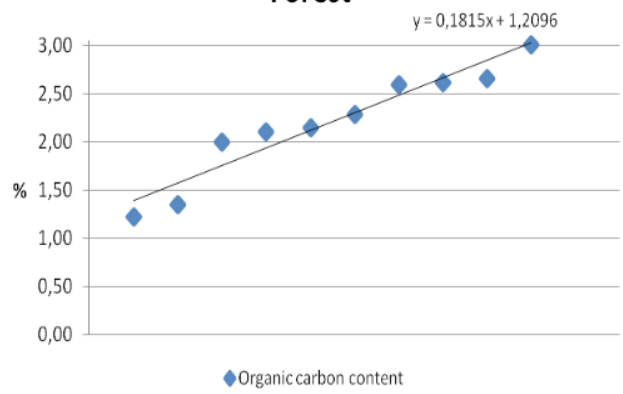

Fig. 1. Organic carbon content in the humus horizons of the examined soils

on loess (silt loam and silt) and positioned on the elevation in close proximity to each other. The research material comprises of 48 samples taken from the humus horizon $(0-15 \mathrm{~cm})$, of which 12 came from sites representing each type of land use considered in the study. Laboratory examination involved the analysis of the organic carbon content (Tiurin method modified) and the fractional composition of humus compounds (Kononowa and Bielczikowa method), as well as $\mathrm{pH}$ (in $1 \mathrm{M} \mathrm{KCl}$ ).

\section{Research results and discussion}

\section{Organic carbon content}

The highest levels of organic carbon content in the humus horizon were found in the forest soils and averaged $2.21 \%$. What is more, the forest soils revealed the highest differences in organic carbon content, from $1.23 \%$ to $3.01 \%$, with a standard bias of $0.57 \%$ (Table 1). This is definitely caused by shade and different plant downfall that dissolves there. The lowest levels were found in the arable land, where the organic carbon content ranged from $0.68 \%$ to $1.27 \%$ with an average of $0.98 \%$ (Fig. 1). A perceptible difference in the organic carbon content between the arable lands and the forest is a result of differences in how the two ecosystems function. In the forest, huge amounts of organic matter created by decomposition of litter and animal remains are incorporated into the cycle every year. In contrast, arable lands are characterized by an open matter cycle, where different nutrients and chemical compounds are removed from the geosystem when the crop is harvested, and the matter cycle incorporates only the decomposition products of the crop stubble as well as any elements added by fertilizers.

Abandonment of land leads to an increase in the soil organic carbon content, while the overgrowth of grasses and tree seedlings that comes shortly after leads to a re-closure of the matter cycle. Decomposition of the litter and animal remains that cover the surface causes an increase in the amount of organic matter. Some 5 years after abandonment, the organic carbon content of the land varies from $1.19 \%$ to $1.60 \%$.
After 20 years of the land being allowed to lay fallow, organic carbon content reaches levels of between $1.05 \%$ and $1.71 \%$, with an average of $1.36 \%$. This is only slightly lower than the levels for land that has been abandoned for 5 years. Yet the land that has been abandoned for longer proves to have different levels, most probably because of the density of its vegetation cover; some $70 \%$ of the research area on that site is covered with 15-year old birches. Where the tree cover is less dense, the land is dominated by grass and especially wood small-reeds. Yet where the tree cover becomes denser, undergrowth is scarce. The differences in the organic carbon content are most probably caused by differences in the supply of plant material that is prone to mineralization and humification.

Similar differences in the organic carbon content of soils of various uses was also demonstrated by research conducted on leached soils (Podzols) and rendzinas (Calcic Leptosols) in Poland by Podstawka-Chmielewska and Kurus (2007), as well as in Costa Rica by Powers (2004), although the landscape in Costa Rica functions differently to that in Poland. These similarities may indicate that land use change has an impact on the soil organic matter content regardless of the environmental conditions. What is more, according to Kosmas et al. (2000) abandonment of the land has significantly increased the soil organic carbon content only of soils created on molten and calcareous rock, while the soils formed on shale exhibit only small differences. Kosmas et al. specify that the type of bedding proves to be more important for the soil organic matter content. This contradicts the results obtained by Geissen et al. (2009), which indicate that there are no differences between the organic carbon content of the soils affected by deforestation and afforestation in Mexico. This lack of consistency means that an overall conclusion is hard to reach.

Fractional composition of humus compounds

The results of laboratory analysis revealed the dominance of humic acids in the humus horizon of the arable land (Fig. 2) at levels that ranged from $10.5 \%$ to $27.7 \%$, while the fulvic 


\begin{tabular}{|c|c|c|c|c|c|c|}
\hline & & \multirow{2}{*}{$\mathrm{pH}$ (in $\mathrm{KCl})$} & \multirow{2}{*}{$\begin{array}{l}\text { Corg } \\
\text { (in \%) }\end{array}$} & \multicolumn{3}{|c|}{ Fractional composition of humus compounds } \\
\hline & & & & $\begin{array}{l}\text { Fulvic acids } \\
\quad \text { (in } \% \text { ) }\end{array}$ & $\begin{array}{l}\text { Humic acids } \\
\text { (in \%) }\end{array}$ & $\begin{array}{l}\text { Fulvic/Humic } \\
\text { acids ratio }\end{array}$ \\
\hline Arable land & $\begin{array}{c}\text { min: } \\
\text { max: } \\
\text { ave: } \\
\text { med: } \\
\text { SD: }\end{array}$ & $\begin{array}{l}5.00 \\
5.72 \\
5.37 \\
5.36 \\
0.22\end{array}$ & $\begin{array}{l}0.68 \\
1.27 \\
0.98 \\
0.99 \\
0.23\end{array}$ & $\begin{array}{c}5.2 \\
19.3 \\
10.5 \\
9.3 \\
4.8\end{array}$ & $\begin{array}{c}10.5 \\
27.7 \\
16.5 \\
14.9 \\
6.4\end{array}$ & $\begin{array}{c}0.5 \\
0.9 \\
0.7 \\
0.7 \\
0.12\end{array}$ \\
\hline $\begin{array}{l}\text { Abandoned } \\
\text { land (5 years) }\end{array}$ & $\begin{array}{c}\text { min: } \\
\text { max: } \\
\text { ave: } \\
\text { med: } \\
\text { SD: }\end{array}$ & $\begin{array}{l}3.77 \\
4.17 \\
4.01 \\
4.01 \\
0.12\end{array}$ & $\begin{array}{l}0.95 \\
1.44 \\
1.28 \\
1.32 \\
0.14\end{array}$ & $\begin{array}{c}8.3 \\
19.6 \\
16.1 \\
17.5 \\
3.5\end{array}$ & $\begin{array}{c}6.11 \\
13.0 \\
9.6 \\
9.1 \\
2.3\end{array}$ & $\begin{array}{c}1.5 \\
1.9 \\
1.7 \\
1.7 \\
0.18\end{array}$ \\
\hline $\begin{array}{c}\text { Abandoned } \\
\text { land ( } 20 \text { years) }\end{array}$ & $\begin{array}{c}\text { min: } \\
\text { max: } \\
\text { ave: } \\
\text { med: } \\
\text { SD: }\end{array}$ & $\begin{array}{l}3.71 \\
4.75 \\
4.00 \\
3.96 \\
0.07\end{array}$ & $\begin{array}{l}0.86 \\
1.47 \\
1.28 \\
1.38 \\
0.22\end{array}$ & $\begin{array}{c}8.2 \\
32.2 \\
16.3 \\
14.3 \\
6.9\end{array}$ & $\begin{array}{c}7.8 \\
19.1 \\
13.3 \\
13.5 \\
4.1\end{array}$ & $\begin{array}{c}1.0 \\
1.7 \\
1.3 \\
1.2 \\
0.24\end{array}$ \\
\hline Forest & $\begin{array}{c}\text { min: } \\
\text { max: } \\
\text { ave: } \\
\text { med: } \\
\text { SD: }\end{array}$ & $\begin{array}{l}3.36 \\
3.82 \\
3.64 \\
3.68 \\
0.15\end{array}$ & $\begin{array}{l}1.23 \\
3.01 \\
2.21 \\
2.22 \\
0.57\end{array}$ & $\begin{array}{c}18.1 \\
25.5 \\
21.1 \\
21.0 \\
2.4\end{array}$ & $\begin{array}{c}4.4 \\
12.5 \\
9.3 \\
9.7 \\
2.4\end{array}$ & $\begin{array}{c}1.9 \\
3.1 \\
2.2 \\
2.1 \\
0.38\end{array}$ \\
\hline
\end{tabular}

Corg - organic carbon content, min - minimum, max - maximum, ave- average, med-median, SD - standard deviation

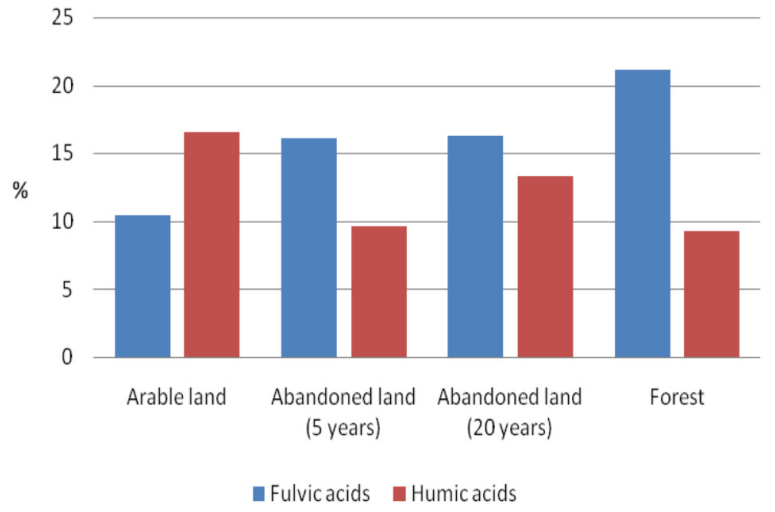

Fig. 2. Average fractional composition of humus compounds in the humus horizons of the examined soils

acid content ranged between $5.2 \%$ and $19.3 \%$. The dominance of humic acids is due to the type of organic substance that decomposing (leaves, roots etc.) and the microorganisms that are causing this decomposition. The main component in these arable soils is cellulose, which is decomposed mainly by environmental bacteria and characterized by weak acid and neutral reactions (Szujecki 1996).

In contrast, in the forest soils the fulvic acids dominate at levels of between $18.1 \%$ and $25.5 \%$, while the humic acids content ranges between $4.4 \%$ and $12.5 \%$. The evident dominance of the fulvic acids in these soils is caused by fungi activity in the decomposition of the organic matter. Fungi live in environments characterized by acid reactions, where the main substance undergoing decomposition is lignin during during which easily-dissolved fulvic acids are generated (Kowaliński, Gonet 1999).

The ratio of fulvic acids to humic acids changes after the land has been abandoned in favor of the latter. The fulvic acids content in the soil samples taken from the land that had been abandoned for 5 -years ranged between $8.3 \%$ and $19 . \%$, whereas the humic acids content ranged between $6.11 \%-13.0 \%$. In the samples taken from the land that had been abandoned for the longer period, there was an increase in the fulvic acids content to $8.2-32.2 \%$ and in the humic acids content to $7.8 \%-19.1 \%$. The difference in the former is probably caused by different amounts of plant cover, while the difference in the latter is the result of the organic substance transformation caused by grass and tree seedlings as well as changes in soil fauna (Rykowski 1990).

Having examined the average fulvic acids to humic acids ratio, we can observe that the highest ratios (averaging 2.2) that signify dominance of the fulvic acids in the humus layer, are encountered in forest soils. Fulvic acids are also predominant in land that has been abandoned for 5 years (average of 1.7) and 20 years (average of 1.3). In contrast, humic acids prevail in the humus layer of the arable land with an average ratio of 0.7 .

Similar observations for the composition of the humus and ratio of fulvic to humic acids were made by Kopeć and Gondek (2001) in their analysis of Małopolska soils, and by Żukowska et. al. (2007) in their examination of Luvisols. Cerli et al. (2008) reported that the increase of fulvic acids with afforestation on land formerly used for agriculture probably indicates podzolization. 


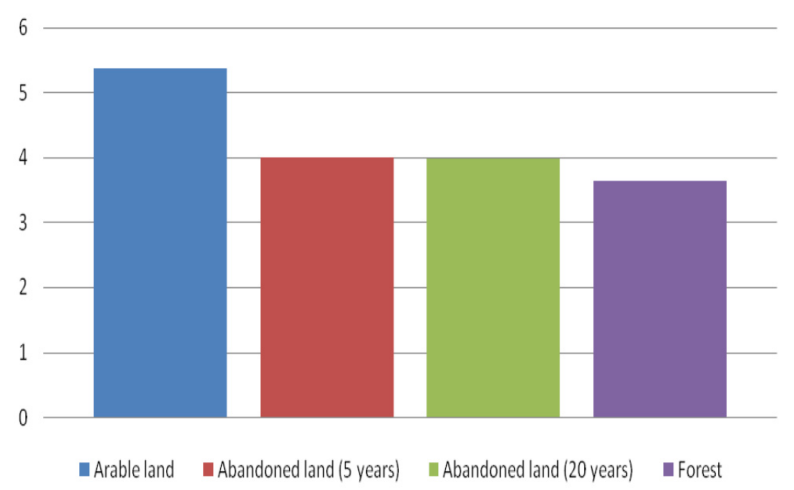

Fig. 3. pH level in humus horizons of the examined soils

Soil reaction

The highest $\mathrm{pH}$ levels of 5.00-5.72 were determined in the upper horizon $(0-15 \mathrm{~cm})$ of the arable soil (Fig. 3). Low acidity in arable soil is an effect of the delivery of alkaline nutrients in mineral fertilizer (Wang et al. 2001). The lowest $\mathrm{pH}$ levels of 3.36-3.82 were determined in the upper horizon of the forest soil and results from the delivery of nutrients both in the atmospheric fall and in the process of litter fall distribution (Pokojska 2005). Given the supremacy of infiltration over evaporation, alkaline nutrients are moved deep into the profile, together with humic acids.

The abandonment of arable lands leads to a change in $\mathrm{pH}$ levels of the upper soil horizon. This is mostly an effect of the discontinuation of the delivery of mineral substances (fertilizers) and the rise in humic acid production, especially fulvic acids. The $\mathrm{pH}$ levels of samples taken from the land that had been abandoned for 5 years ranged between 3.77 and 4.17, while for land that had been abandoned for 20 years they ranged between 3.71 and 4.75 . The relatively small difference in the soil reaction indicates that the largest changes in $\mathrm{pH}$ levels occur in the first years after abandonment and that they are generally constant until the young forest starts to grow (birches, in this case). Similar relationships between $\mathrm{pH}$ levels were indicated in research by Skłodowski and Zarzycka (1995) on acid brown-earth soils (Dystric Cambisols) and in research conducted by Łętowska and Straczyńska (2001) on brown-earth soils (Cambisols). As the soil reaction is characterized by a relatively quick response, it has become a generally-used indicator of changes occurring in the landscape (Ritter et al 2003).

\section{Conclusion}

Land use change (when a forest ecosystem turns into a tillage system) leads to a vast transformation in vegetation and soils. In the process of secondary succession, arable lands are overgrown with grasslands and pioneer tree seedlings. As a result, the amount of organic matter increases and its decomposition contributes directly to an increase in the organic carbon content in the humus horizon of the soil. These changes appear slowly, but after 5 years from abandonment the increase is already around $25 \%$. As time progresses, a small decrease in organic carbon content can be noted.

These changes also cause transformation in the fractional humus compound. The soils of the land that had been abandoned had higher levels of fulvic than humic acids. This is a characteristic feature of forest soils. In contrast, the soils of arable lands had higher humic acid levels than fulvic acid levels.

As a result of the increased fulvic acid production in the abandoned soils, the soil reaction changes notably. The arable soils show neutral or slightly acid soil reactions, while abandoned soils show definite acid soil reactions. A decrease in the soil reaction was evident 5 years after the abandonment of the arable land and was close to the level found in forest soils.

These results show that secondary succession on abandoned land has a direct impact on the geochemical properties of the soil as it transforms into forest soils. The most rapid change is manifested 5 years after the land is abandoned, after which it gradually decelerates. For these reasons, the findings presented in this paper confirm that the vegetation and soil are reliable indicators of landscape change.

\section{References}

Baran-Zgłobicka, B, Harasimiuk, M, Zgłobicki, W 2001, 'Contemporary transformation of agricultural landscapes in South-East Poland Loess Upland Region', Problemy Ekologii Krajobrazu, vol. X, pp. 269-275, (In Polish, summary in English).

Cerli, C, Celi, L, Kaizer, K, Guggenberger, G, Johansson, M,B, Cignett, A, Zanini, E 2008, 'Changes in humic substances along an age sequence of Norway spruce stands planted on former agricultural land', Organic Geochemistry, vol. 39, pp. 1269-1280.

Chmielewski, TJ 2012, Landscape systems. StructureFunctioning-Planning, PWN, Warszawa (In Polish).

Degórski, M 2005, 'Soil as an indicator of the natural environment changes', Przegl. Geogr. vol. 77, no. 1. pp. 3755 (In Polish, summary in English).

Geissen, V, Sánchez-Hernandez, R, Kampichler, C, Ramos-Reyes, R, Sepulveda-Lozada, A 2009, 'Effect of land use change on some properties of tropical soils An example from Southeast Mexico', Geoderma, vol. 151, pp. 87-97.

Kondracki, J 2009, Polish Regional Geography, PWN, Warszawa (In Polish).

Kopeć, M, Gondek, K 2001, 'Humus fractional composition of the selected soils in the Małopolska Province', Acta Agrophysica, vol. 50, pp. 139-146.

Kowaliński, S, Gonet S 1999, 'Soil organic matter' in Pedology ed S Zawadzki, PWRiL, Warszawa (In Polish).

Kosmas, C, Gerontidis, St, Marathianou, M 2000, 'The effect of land use change on soil and vegetation over various litilogical formation on Lesvos (Greece)', Catena, vol. 40, pp. 51-68.

Łętowska, A, Strączyńska, S 2001, 'Selected physicochemical and chemical soil properties on abandoned and arable lands', Zesz. Prob. Post. Nauk Rol., vol. 478, pp. 241-248. (In Polish, summary in English).

Ostaszewska, K 1992, 'The use of landscape geochemical methods for physico-geographical research: A case study of the environs of Frankfurt am Main', Prace $i$ Studia Geograficzne, vol. 14, pp. 39-55 (In Polish, summary in English).

Ostaszewska, K 2002, The Geography of Landscape, PWN, Warszawa (In Polish).

Perelman, A, J 1971, The Geochemistry of Landscape, PWN, Warszawa (In Polish).

Podstawka-Chmielewska, E, Kurus, J 2007, 'The influence of multiyear arable land fallowing on chemical soil properties', Zesz. Prob. Post. Nauk Rol, vol. 520, pp. 845-850 (In Polish, summary in English).

Pokojska, U 2005, 'Soil reaction', in Ecologico-pedological research, $\mathrm{R}$ Bednarek, $\mathrm{H}$ Dziadowiec, U Pokojska, Z Prusinkiewicz, PWN, Warszawa. 
Powers, J.S 2004, 'Changes in soil carbon and nitrogen after contrasting land-use transitions in north eastern Costa Rica', Ecosystems, vol. 7, pp. 134-146.

Richling, A 1982, Methods of research for Complex Physical Geography, PWN, Warszawa (In Polish).

Richling, A, Solon, J 2011, The Ecology of Landscape, PWN, Warszawa (In Polish).

Ritter, E, Vesterdal, L, Gundersen, P 2003, 'Changes in soil properties after afforestation of formerly intensively managed soils with oak and Norway spruce', Plant and Soil, vol. 249. pp. 319-330.

Rykowski, K 1990, 'Forest conservation problems on abandoned lands', Sylwan, vol. 134, pp. 75-88 (In Polish, summary in English).

Skłodowski, P, Zarzycka H 1995, 'Soil utilization impact on selected chemical properties', Roczniki gleboznawcze, vol. 46, pp. 37-44. (In Polish, summary in English).
Szujecki, A 1996, 'Ecological aspects of forest reconstruction on abandoned lands', Prace IBL, vol. 27 (In Polish).

Wang, J, Bojie, F, Quu, Y, Chen, L 2001, 'Soil nutrients in relation to land use and landscape position in the semiarid small catchment on the loess plateau in China', J. of Arid Environments, vol. 48, pp. 537-550.

Widacki, W 1979, 'On the functioning of geosystems', Folia Geogr. Ser. Geogr.-Phys., vol. 12, pp. 137-145, (In Polish, summary in English).

Żukowska, G, Flis-Bujak, M, Baran, S, Wójcikowska-Kapusta, A 2007, 'The influence of soil lying fallow on the quantity and quality of organic matter in albic Luvisols', Zesz. Prob. Post. Nauk Rol., vol. 520, pp. 865-871 (In Polish, summary in English). 